\section{Rancang Bangun Aplikasi E- Commerce Produk Desa Binaan Fakultas Teknik ULM Kecamatan Cempaka Banjarbaru}

\section{Yuslena Sari ${ }^{1}$, Husnul Khatimi ${ }^{1}$, Muhammad Alkaff $^{1}$, Andreyan Rizky Baskara ${ }^{1}$, Muti'a Maulida ${ }^{1}$, Halimah², Nurul Qamariah ${ }^{2}$}

1Dosen Program Studi Teknologi Informasi Fakultas Teknik Universitas Lambung Mangkurat

2Mahasiswa Program Studi Teknologi Informasi Fakultas Teknik Universitas Lambung Mangkurat

\section{m.alkaff@ulm.ac.id}

Desa Cempaka yang terletak di Banjarbaru Kalimantan Selatan merupakan desa pengrajin sasirangan dan produk-produk kerajinan lainnya. Banyak masyarakat yang berdatangan kesana untuk membeli kain sasirangan maupun produk buatan tangan lainnya karena dikenal dengan kualitasnya yang bagus. Tetapi dalam pengelolaan jual beli di Desa Cempaka, pembeli harus datang langsung ke tempat untuk melihat barang dan melakukan proses transaksi jual beli. Hal ini akan memakan waktu untuk pembeli dan bisa menyebabkan kurangnya minat pembeli untuk kerajinan di Desa Cempaka Banjarbaru. Dengan berkembangnya teknologi informasi saat ini banyak aplikasi yang membuat Online Shop untuk lebih mudah melakukan jual - beli dan menghemat waktu tanpa datang langsung ke toko yang kita inginkan. Perkembangan bisnis menggunakan Online Shop pun semakin meningkat seiring dengan banyaknya masyarakat yang menggunakan internet. Untuk itu kami membuat aplikasi Online Shop untuk memfasilitasi kerajinan yang ada di Desa Cempaka Banjarbaru. Penelitian ini mengaplikasikan metode waterfall dalam pengembangan sistemnya. Metode waterfall dipilih karena system ini akan berkelanjutan seiring dengan perkembangan bisnis di Desa Cempaka Banjarbaru. Tujuan dari penelitian adalah untuk mempermudah masyarakat yang ingin membeli produk kerajinan di desa cempaka sehingga dapat meningkatkan penjualan produk kerajinan dari Desa Cempaka.

Kata kunci : online shop, waterfall, bisnis, Cempaka

Diajukan: 13 September 2019

Direvisi: 14 September 2019

Diterima: 2 Oktober 2019

Dipublikasikan online: 3 Oktober 2019

\section{Pendahuluan}

Banjarbaru merupakan salah satu kota yang berada di Provinsi Kalimantan Selatan dengan status sebagai Kotamadya sejak tahun 1999 (ULM, 2019). Dengan luas wilayah $371,28 \mathrm{~km} 2$, Banjarbaru memiliki memiliki pesona wisata yang sangat beragam yang tersebar di 5 Kecamatan yang dimilikinya, salah satunya Kecamatan Cempaka (www.banjarbarukota.go.id). Kecamatan Cempaka memiliki luas 146,70 km yang merupakan kawasan terluas dari Kota Banjarbaru dengan jumlah penduduk tercatat pada tahun 2015 sebanyak 32.990 jiwa (www.banjarbarukota.go.id). Kecamatan Cempaka terbagi menjadi 4 (empat) wilayah Kelurahan dimana salah satunya yaitu Kelurahan Cempaka atau sering disebut Kawasan Cempaka.

Kawasan Cempaka terkenal dengan tempat pendulangan intan-nya sejak ditemukannya sebuah intan seberat 166,7 karat di tahun 1960-an. Selain pendulangan intan, kawasan ini juga terkenal sebagai penghasil berbagai produk kerajinan dan makanan seperti kain sasirangan, barang kerajinan purun, kain arguci, kue 41 dan masih banyak lagi. Kegiatan produksi ini merupakan salah satu mata pencaharian yang banyak dijalani oleh penduduk kawasan Cempaka. Kegiatan produksi kerajinan ini merupakan salah satu bentuk ekonomi kreatif yang dimiliki oleh kawasan ini, dimana sejalan dengan visi kawasan Cempaka yaitu 'Kawasan budaya bernuansa religi dan ekonomi kreatif'.

Namun kegiatan ekonomi kreatif yang dilakukan oleh masyarakat kawasan Cempaka ini belum terkoordinir dengan baik dimana penjualan produk kerajinan masih dilakukan secara terpisah di masingmasing pengrajin. Jika calon pembeli ingin membeli hasil kerajinan Cempaka dapat datang langsung ke rumah pengrajinnya atau memesan melalui telepon. Kondisi ini cukup menyulitkan calon pembeli karena tidak dapat mengetahui informasi tentang pilihan produk dan ketersediannya di pengrajin sehingga tidak sedikit yang mengurungkan niat untuk membeli. Hal ini tentu menjadi kerugian bagi pengrajin karena produk yang dihasilkan tidak terjual dengan baik sekaligus mempengaruhi pendapatan masyarakat pengrajin di kawasan Cempaka. Berdasarkan hal tersebut, Fakultas Teknik Universitas Lambung Mangkurat (ULM) sebagai pembina dari Kawasan Cempaka Banjarbaru memiliki agenda untuk membantu dalam peningkatan nilai ekonomi dari produksi kerajinan di Kawasan Cempaka.

Cara mensitasi artikel ini:

Sari, Y., Khatimi, H., Alkaff, M., Baskara, A.R., Maulida, M., Halimah, Qamariah., N (2019) Rancang Bangun Aplikasi E-Commerce Produk Desa Binaan Fakultas Teknik ULM Kecamatan Cempaka Banjarbaru. Buletin Profesi Insinyur 2(2) 076-080 
Bisa dilihat pada Gambar 1 salah satu produk kerajinan yang ada di kawasan cempaka.

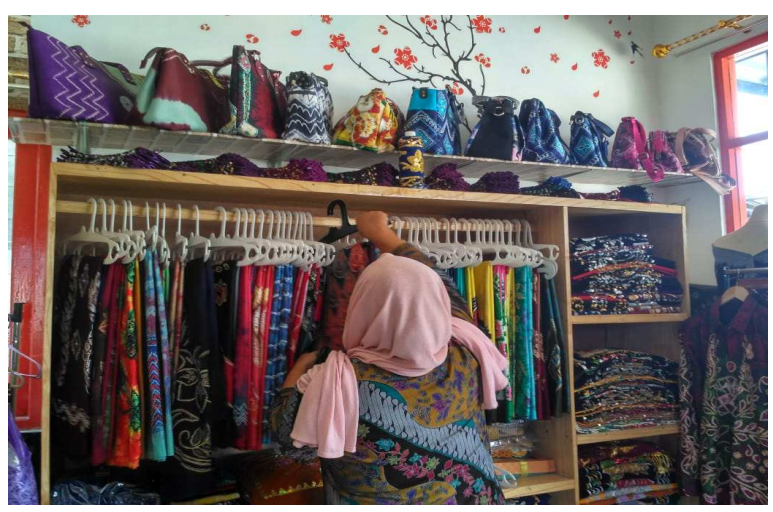

Gambar 1. Salah satu toko produk kerajinan yang ada di kawasan Cempaka

Pengelolaan kegiatan tersebut dilakukan oleh kewirausahaan mahasiswa Fakultas Teknik ULM dengan tujuan memfasilitasi pengrajin Cempaka Banjarbaru untuk pemasaran dan penjualan produk kerajinannya pada jangkauan pasar lebih luas. Pada penelitian yang dilakukan oleh Sandy Kosasi dengan tujuan mempermudah pengenalan dan penjualan produk oleholeh khas Pontianak secara global dilakukan dengan pengembangan sistem Online Shop. Penggunaan sistem ini dapat memperluas pangsa pasar dan menumbuhkan daya saing global oleh-oleh khas Pontianak (Kosasi, 2015). Sama halnya dengan penelitian oleh Shabut Miftah Maulana dkk., yang juga mengembangkan website Online Shop sebagai media promosi dan penjualan elektronik pada toko Pastbrik Kota Malang (Maulana dkk, 2015). Penelitian lainnya dilakukan oleh D. L. Fithri, A. P. Utomo, dan F. Nugraha yang memiliki tujuan untuk meningkatkan kuantitas penjualan bordir kurnia Kudus melalui perluasan cakupan pemasaran bukan hanya di Kota Kudus tapi seluruh Indonesia. Untuk mencapai tujuan ini, penelitian tersebut memanfaatkan Online Shop untuk mengoptimalkan pemasaran produk tersebut (Fithri, 2017).

\section{Metode}

Pembuatan aplikasi ini menggunakan bahasa pemrograman PHP, dengan menggunakan framework laravel. Proses pengembangan aplikasi ini mengadaptasi dari model pengembangan Waterfall. Aplikasi ini bertujuan untuk memudahkan pembeli dalam membeli barang agar tidak harus datang ketempat penjualan dan Fakultas Teknik pun bisa mengawasi jalannya proses jual beli.

\section{Hasil Kerja}

\section{Identifikasi Masalah}

Berdasarkan Penjelasan pada latar belakang yang telah dianalisa pada desa binaan FT ULM kecamatan Cempaka, Banjarbaru, banyak masyarakat yang membuat produk buatan sendiri untuk dijual. Adapun untuk permasalahan yang terjadi sejauh ini masyarakat Cempaka hanya mengenal proses jual beli yang dilakukan di tempat penjualan.

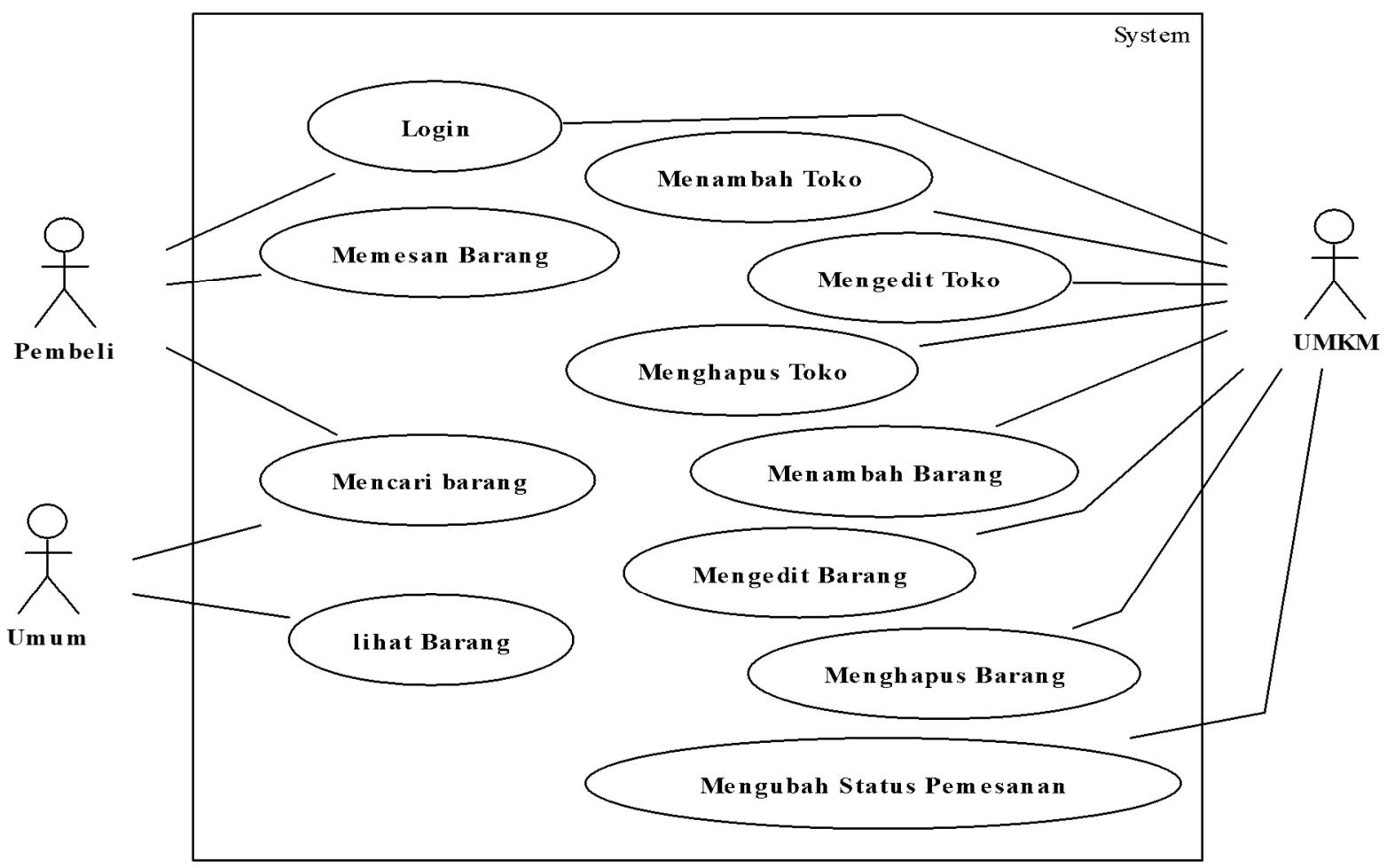

Gambar 2. Diagram Usecase aplikasi olshop Cempaka Banjarbaru 
Untuk meningkatkan nilai jual produk, Fakultas Teknik memfasilitasi dengan sebuah aplikasi Online Shop. Online Shop merupakan sarana atau toko untuk menawarkan barang dan jasa lewat internet sehingga pengunjung Online Shop dapat melihat barang-barang di toko online.

Akan tetapi masih ada beberapa masyarakat desa Cempaka yang belum paham dan mengerti masalah komputer dan internet, maka dari itu UMKM Fakultas Teknik akan ikut membantu dalam menjalankan aplikasi Online Shop ini.

\section{Perancangan Sistem}

Berdasarkan hasil penggalian kebutuhan sistem yang ingin di buat maka muncul beberapa aktor yang terlibat dalam proses jual beli ini yang didapatkan dari sebuah diskusi dan juga referensi dari Online Shop yang sudah ada, yaitu:

1. Pembeli merupakan calon pembeli produk dari toko online. Pembeli adalah pengunjung yang telah melakukan proses pendaftaran. Pembeli hanya dapat melihat dan memesan produk namun tidak berhak untuk mengubah data produk.

2. Admin merupakan UMKM dan UMKM akan mengelola produk yang berasal dari kelurahan cempaka, mengelola laporan pemesanan. UMKM dapat mengubah data produk tapi tidak bisa untuk membeli produk.

3. Umum merupakan pengunjung Online Shop yang belum melakukan pendaftaran. Umum hanya mampu melihat data produk dan toko tetapi tidak bisa melakukan pembelian.

Kebutuhan pengguna yang perlu disediakan di dalam sistem dapat dilihat pada Gambar 2.

Use case diagram yang terlihat pada Gambar 2 menjelaskan bahwa Pembeli pada sistem memiliki hak akses untuk login, memesan barang, dan mencari barang. Sedangkan pada admin menjelaskan pada sistem juga bisa login lalu menambah, mengedit, dan menghapus data toko dan barang serta dapat mengubah status pemesanan.

Penjelasan detail untuk masing-masing Use case mengenai aktivitas, aktor, beserta deskripsinya bisa dilihat pada Tabel 1.

Tabel 1. Penjelasan Masing-masing Usecase

\begin{tabular}{|c|c|c|c|}
\hline Kode & Aktivitas & Aktor & Deskripsi \\
\hline UCO1 & Login & $\begin{array}{l}\text { UMKM } \\
\& \\
\text { Pembeli }\end{array}$ & $\begin{array}{l}\text { Use case digunakan } \\
\text { oleh UMKM dan } \\
\text { pembeli }\end{array}$ \\
\hline $\mathrm{UCO} 2$ & $\begin{array}{l}\text { Memesan } \\
\text { Barang }\end{array}$ & Pembeli & $\begin{array}{l}\text { Use case digunakan } \\
\text { oleh pembeli untuk } \\
\text { memesan barang }\end{array}$ \\
\hline UCO3 & $\begin{array}{l}\text { Menambah } \\
\text { Toko }\end{array}$ & UMKM & $\begin{array}{l}\text { Use case digunakan } \\
\text { oleh UMKM untuk } \\
\text { menambahkan toko }\end{array}$ \\
\hline UCO4 & $\begin{array}{l}\text { Mengedit } \\
\text { Toko }\end{array}$ & UMKM & $\begin{array}{l}\text { Use case digunakan } \\
\text { oleh UMKM untuk } \\
\text { mengedit toko }\end{array}$ \\
\hline UCO5 & $\begin{array}{l}\text { Menghapus } \\
\text { Toko }\end{array}$ & UMKM & $\begin{array}{l}\text { Use case digunakan } \\
\text { oleh UMKM untuk } \\
\text { menghapus toko }\end{array}$ \\
\hline
\end{tabular}

\begin{tabular}{|c|c|c|c|}
\hline Kode & Aktivitas & Aktor & Deskripsi \\
\hline UCO6 & $\begin{array}{l}\text { Menambah } \\
\text { Barang }\end{array}$ & UMKM & $\begin{array}{l}\text { Use case digunakan } \\
\text { oleh UMKM untuk } \\
\text { menambahkan } \\
\text { barang untuk dijual }\end{array}$ \\
\hline $\mathrm{UCO} 7$ & $\begin{array}{l}\text { Mengedit } \\
\text { Barang }\end{array}$ & UMKM & $\begin{array}{l}\text { Use case digunakan } \\
\text { oleh UMKM untuk } \\
\text { megedit barang } \\
\text { untuk dijual }\end{array}$ \\
\hline $\mathrm{UCO} 8$ & $\begin{array}{l}\text { Menghapus } \\
\text { Barang }\end{array}$ & UMKM & $\begin{array}{l}\text { Use case digunakan } \\
\text { oleh UMKM untuk } \\
\text { menghapus barang } \\
\text { untuk dijual }\end{array}$ \\
\hline UCO9 & $\begin{array}{l}\text { Mengubah } \\
\text { Status } \\
\text { Pemesanan }\end{array}$ & UMKM & $\begin{array}{l}\text { Use case digunakan } \\
\text { oleh UMKM untuk } \\
\text { mengubah status } \\
\text { pemesanan } \\
\text { pemberitahuan } \\
\text { seperti barang } \\
\text { sedang dikemas, } \\
\text { barang telah dikirim. }\end{array}$ \\
\hline UCO10 & Lihat Barang & Umum & $\begin{array}{l}\text { Use case digunakan } \\
\text { oleh umum bisa } \\
\text { melihat barang tanpa } \\
\text { harus login terlebih } \\
\text { dahulu }\end{array}$ \\
\hline UCO11 & $\begin{array}{l}\text { Mencari } \\
\text { Barang }\end{array}$ & $\begin{array}{l}\text { Umum \& } \\
\text { Pembeli }\end{array}$ & $\begin{array}{l}\text { Use case digunakan } \\
\text { oleh umum bisa } \\
\text { mencari barang tanpa } \\
\text { harus login terlebih } \\
\text { dahulu ataupun } \\
\text { sudah login untuk } \\
\text { pembeli }\end{array}$ \\
\hline
\end{tabular}

\section{Implementasi}

Dari hasil perancangan, berikutnya dilakukan tahap implementasi sehingga menjadi sebuah sistem yang dapat digunakan. Sistem diimplementasikan menggunakan bahasa pemrgoraman PHP dan framework Laravel. Hasil implementasi untuk halaman beranda dapat dilihat pada Gambar 3.

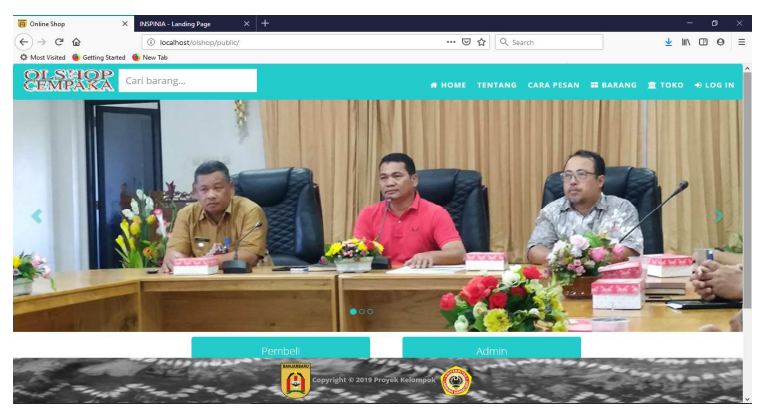

Gambar 3. Halaman Beranda

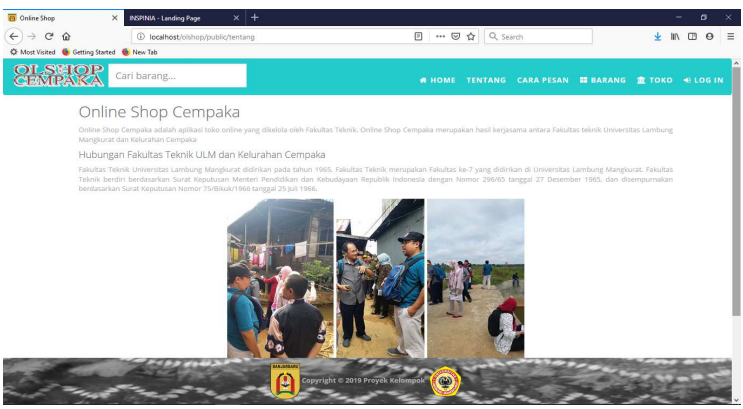

Gambar 4. Halaman Tentang 
Halaman tentang merupakan halaman yang tampil setelah mengakses menu tentang. Tampilan halaman tentang dapat dilihat di Gambar 4.

Halaman cara pesan merupakan halaman yang menampilkan informasi tata cara pesan menggunakan aplikasi olshop ini. Tampilan halaman cara pesan dapat dilihat di Gambar 5.

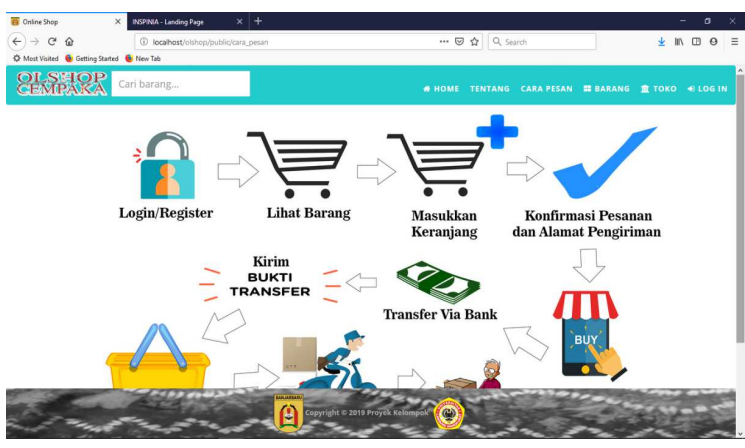

Gambar 5. Halaman Cara Pesan

Halaman barang merupakan halaman yang menampilkan informasi daftar barang apa saja yang dijual. Tampilan halaman barang dapat dilihat di Gambar 6 .
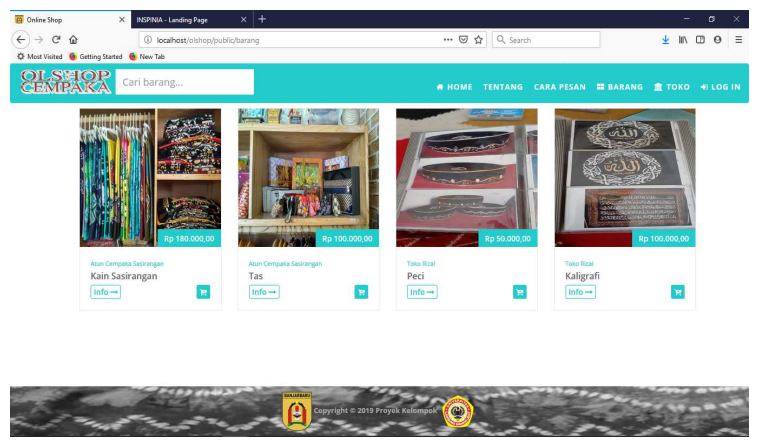

Gambar 6. Halaman Barang

Dalam setiap barang juga ada tombol info yang mengarah ke halaman detail barang yang berisi informasi barang secara lebih detail seperti yang terlihat pada Gambar 7. Dalam halaman detail barang terdapat tombol tambah yang fungsinya sama seperti tombol keranjang kecil pada halaman barang.
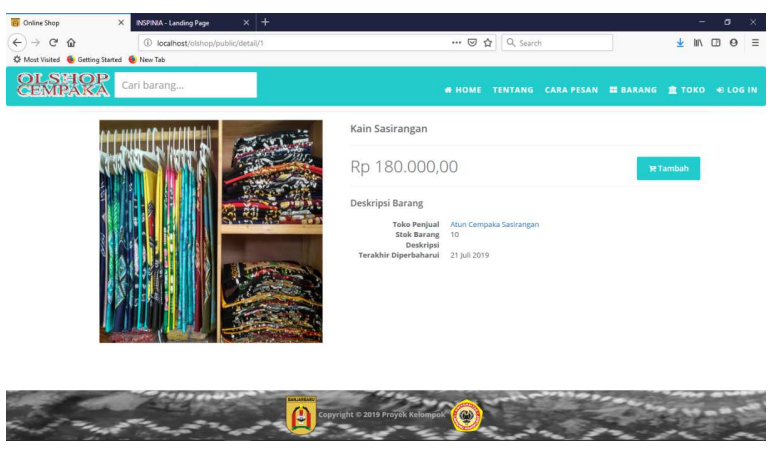

Gambar 7. Halaman Detail Barang

Halaman toko menampilkan peta lokasi toko yang di dalamnya terdapat pin berwarna biru yang berfungsi untuk menandai lokasi toko-toko yang menjual barang di aplikasi Online Shop ini. Ketika pin tersebut di klik akan menampilkan popup yang berisi gambar dan tautan nama toko seperti yang terlihat pada Gambar 8.

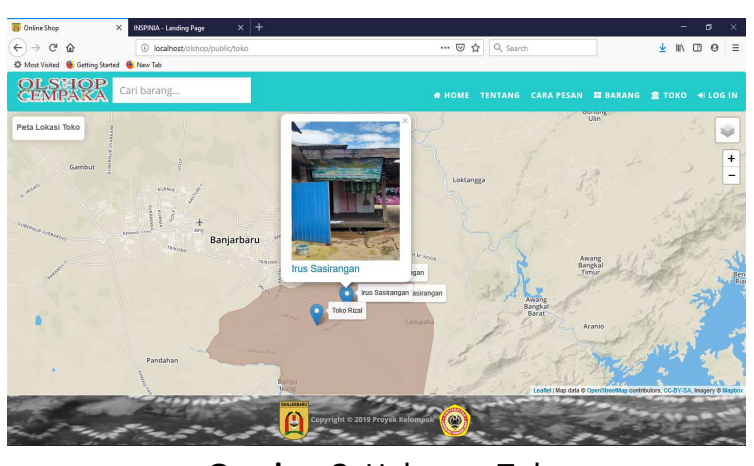

\section{Gambar 8. Halaman Toko}

Halaman keranjang adalah halaman yang tampil setelah mengakses menu keranjang. Halaman ini berfungsi untuk memastikan lagi barang yang akan dipesan. Tampilan halaman keranjang dapat dilihat pada Gambar 9 berikut.

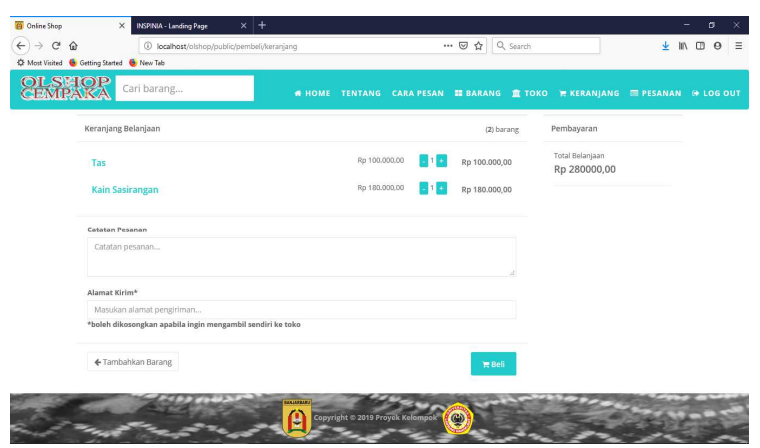

Gambar 9. Halaman Keranjang

Halaman pesanan merupakan halaman yang tampil setelah memilih tombol beli di halaman keranjang. Halaman ini juga bisa diakses dengan memilih menu pesanan. Tampilan halaman pesanan dapat dilihat pada Gambar 10 berikut. Halaman pesanan menampilkan tabel daftar pesanan beserta statusnya dari pembeli yang sedang login.

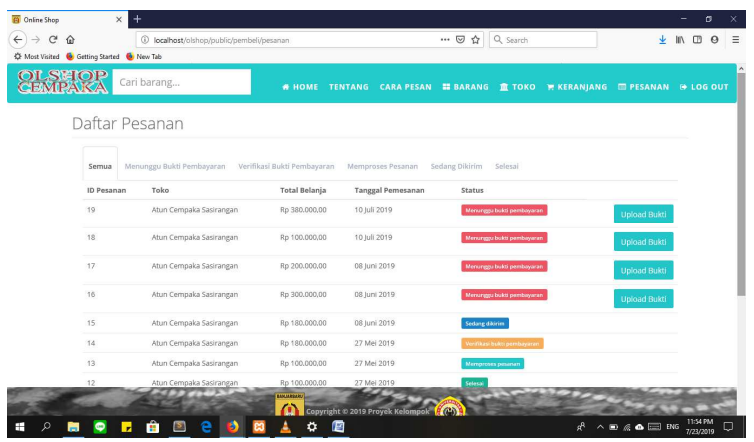

Gambar 10. Halaman Pesanan

\section{Pengujian Sistem}

Untuk mengetahui apakah sistem bekerja sesuai dengan harapan, dilakukan uji fungsional dengan menggunakan metode Black Box Testing. Metode Black Box Testing merupakan metode pengujian software yang digunakan untuk menguji perangkat lunak tanpa mengetahui struktur internal kode. Testing ini hanya memandang perangkat 
lunak dari sisi spesifikasi dan kebutuhan yang telah didefinisikan pada saat awal perancangan.

Pengujian Black Box dilakukan dengan menguji semua fungsi pada sistem. Kemudian hasil dari pengujian disimpan dalam sebuah tabel yang berisi kolom Skenario Uji, Realisasi yang diharapkan, Hasil Uji, dan Status Uji. Kolom Skenario Uji menjelaskan aksi-aksi yang dapat dilakukan oleh pengguna. Realisasi yang diharapkan menjelaskan hasil yang seharusnya ketika Skenario Uji dijalankan. Hasil uji menjelaskan bagaimana hasil sebenarnya dari Skenario Uji. Status Uji menjelaskan apakah Skenario Uji berjalan sesuai dengan Realisasi yang dijalankan, jika iya maka Status Uji adalah Diterima dan jika tidak maka status Ditolak.

Dari pengujian yang dilakukan didapatkan hasil yaitu $100 \%$ berhasil artinya sistem yang dibangun sudah berjalan sesuai yang diharapkan.

\section{Kesimpulan}

Untuk meningkatkan nilai jual produk di desa binaan kecamantan Cempaka, maka Fakultas Teknik memfasilitasi dengan sebuah aplikasi Online Shop. Online Shop merupakan sarana atau toko untuk menawarkan barang dan jasa lewat internet sehingga pengunjung Online Shop dapat melihat barang-barang di toko online. Berdasarkan hasil pengujian yang telah dilakukan aplikasi Online Shop yang telah dibangun sudah berjalan sesuai yang diharapkan. Dengan adanya aplikasi Online Shop ini diharapkan dapat meningkatkan keingintahuan masyarakat terhadap Kawasan Cempaka serta produk yang dihasilkan penduduknya.

\section{Referensi}

Fithri, D. L., Utomo, A. P., Nugraha, F. (2017) Pemanfaatan ECommerce Populer Untuk Optimalisasi Pemasaran Produk Pada Kub Bordir Kurnia Kudus, vol. 8, no. 2, pp. 819-824

Kosasi, S (2015) "Perancangan Sistem E-Commerce Untuk Memperluas Pasar Produk Oleh-Oleh Khas Pontianak," pp. 110-119.

Maulana, S.M., Susilo, H., dan Riyadi (2015) Implementasi ECommerce Sebagai Media Penjualan Online (Studi Kasus Pada Toko Pastbrik Kota Malang), vol. 29, no. 1.

ULM (2019) Universitas Lambung Mangkurat, "Sejarah Singkat Fakultas Teknik." [Online]. Available: ft.ulm.ac.id. [Accessed: 23-Mar-2019]. (2019) "Wisata Kota Banjarbaru." [Online]. Available: http://www.banjarbarukota.go.id/wisata. [Accessed: 23-Mar-2019].

, (2019) "Data Geografis: Kota Banjarbaru." [Online]. Available: http://www.banjarbarukota.go.id/potensialam. [Accessed: 23-Mar-2019]. 